\title{
Mendidik Karakter Anak melalui Model Pembelajaran Berbasis Proyek (Sebuah Desain Pembelajaran Matematika yang Berkarakter)
}

\author{
Miftha Indasari \\ Mifthaindasari21@gmail.com \\ Universitas PGRI Palembang \\ Character Education to Children through Project-based Learning Model \\ (A Math Instructional Design)
}

\begin{abstract}
Character education in the realm of education in elementary school is crucial to be invested because basic education is the beginning of the moral application in human life. In school, children spend their time studying and interacting in their social life. There are several ways in teaching the values of character in school, one of which is to insert the values of characters in the mathematics learning. A real teacher simply directs and creates a learning plan that can accommodate the appearance of the character. One of the learning models that can stimulate the insertion of character values in students is the Project-based Learning model. Thus, the students will learn through the project and indirectly will also emerge the understanding of the character values that exist in the project activities.
\end{abstract}

Keywords: Character, learning, project

Received date: 13 Juli 2017

Article Info

Revised date: 04 Agustus 2017 Accepted date: 19 Desember 2017

\section{INTRODUCTION}

Character education implemented in schools is not intended to create a new order in terms of morals and ethics, instead of trying to restore the character and culture of the Indonesian nation that has begun to erode from the lives of its people, especially in students. Therefore the return of this character is manifested in an education taught from early ages by the school and society. Thus it should be a character-based education taught from basic education. Imam Al Ghazali also asserts that, "since childhood the child is neglected, it is likely that he will grow up to be a child with bad behavior, lying, envying, stealing, spreading slander, interfering in other people's affairs,... Those bad qualities can be prevented if the child is well educated and treated and loving." (Basya, 2009: 15).

In the Qur'an on Surah Ash-Sham (91) verse 8 Allah says "Allah inspires the soul (the path) of ungodliness and piety". This indicates that man has been blessed with two qualities of good and evil. Selection of two possible properties will form different characters in each individual. The potential of good and bad traits has also been studied by western researchers who say that human nature is influenced by three factors, namely: the nature (the flow of nativism pioneered by Schopenhauer) is that humans are born with the potential of each character, the environment (the flow of empiricism pioneered John Lock) is that human character can be affected by the environmental conditions in which it exists, and the nature and environment (the convergence stream pioneered by Willian Stern) is that human character may be influenced by both factors, namely innate and environmental. Thus, a persons' character is built from the time he was born until he became a part of society. However, long before western researchers expounded the hadith on the factor of character formation of the child, Prophet Muhammad SAW has said "the Son was born in a holy state, his parents made him Majusi or Christian" (Muslim. This suggests that a child born in a holy state, carrying the potential of each character will be able to change briefly. 
If the environment that makes up his personality is good then most likely the characters formed in the child will be good too, and vice versa. So, this is where the importance of the role of parents and teachers in the formation of children's character from an early age. In school, children spend their time studying and interacting with their social life. Teachers as facilitators in learning in the class are required to direct the potential and character of the child so that later students can be intelligent in cognitive but also intelligent in managing the attitude and emotions for social life.

The struggle that is based on the nature of selflessness and compassion makes the intention of sincerity of these fighters as the struggle for independence of the Indonesian nation. Then the mentality of cooperation between the people and leaders, courage against the invaders though only armed with bamboo spears capable of paralyzing the Dutch armed forces. So fierce mentality of the Indonesian fighters at that time. They were not only the elders, but also tough young people. Young generation today tend to avoid hard work of the early fighters mentioned above. So it is necessary to plant the values of character in the younger generation as the nation's heir. Second, is about the juridical reason. This juridical reason is the basis of legislation regarding the implementation of character education. The rules are: 1) The National Long-Term Development Year 2005-2025 in Law of the Republic of Indonesia Number 17 Year 2007 explains that the purpose of education is "the realization of a national character are the character of strong, competitive, noble, and Pancasila-based moral, which is characterized within a diverse background, faithful, and fear to the God Almighty, virtuous, polite, having mutual cooperation, spiritful, patriotic, dynamic, and science-oriented; 2) Law no. 20 of 2003 on National Education System Article 3 states that "National education functions to develop the ability and form the character and civilization of a dignified nation in order to educate the nation's life, aims for the development of potential learners to be a man of faith and fear to God Almighty, noble, healthy, knowledgeable, capable, creative, independent, and become a democratic and honest citizen."

Third, the sociological reasons suggests character education gets special attention when a widespread deviant behavior in society happens, especially from adolescents whose attitude do not reflect the character of Indonesia. This is what makes the government is trying to revise the learning activities in schools toward the improvement of character. The public demand for more noble and spiritual intelligent output is increasingly giving influence to the government in the process of curriculum formulation which requires the inclusion of character education in every learning activity. Fourth, the pedagogical reasons. Character education is done in order to educate citizens (in this case the students) to walk on the way of life in accordance with the rules of values and norms in accordance with human nature oriented with truth and nobility.

\section{DEVELOPMENT OF CHARACTER VALUE IN LEARNING PROCESS}

There are several ways in teaching the values of character in school, one of which is to insert the values of character into learning in accordance with learning. This is often referred to as a hidden curriculum. Implementation is done by teachers who act as student facilitators in developing character values. The 2013 curriculum that has been designed by the government since 2013 has provided learning that can train students in developing their inner character. The real teacher simply directs and creates a learning plan that can accommodate that character can appear. In mathematics learning even the character of students can be developed through authentic activities on students. For example through a project-based learning model. This learning model has also become one of the instructional models suggested to be implemented by teachers in schools because it contains authentic learning activities. 
In practice, this project-based learning model should include activities that can accommodate the cognitive, psychomotor, and affective abilities of children. Learning will lead to an assessment of the child's ability to apply the material or some of the material they have acquired in the classroom. The activities will begin with the determination of fundamental questions, then, plan the project, to test results and monitoring. In addition to develop a math problem solving skills in project activities, students will be trained in moral thinking through the conclusions they will get. Teacher as facilitator only monitor and assist and guide students in carrying out the project.

Project granters should have goals tailored to the curriculum. The establishment of a good attitude or character is an expected goal within the student. Activities based on the personal experiences of students are expected to impress on the hearts of students so that they will remember and apply the knowledge gained into their daily lives.

Some of the values of characters that have been proclaimed by the Ministry of National Education (Suyadi, 2013: 7), namely religious, honest, tolerance, discipline, hardworking, creative, independent, democratic, curious, having spirit of nationality, friendly / communicative, love peace, love to read, care about the environment, care to others, and responsibility. In the learning, the teacher can choose several characters to be developed which activities are also tailored to the learning objectives.

\section{LEARNING BASED ON A CREATED PROJECT}

The integration of character values will depend on the teacher's ability and commitment in its application in classroom learning so that there is no inconsistency between theory and practice in the field. The existence of gaps in the implementation of character education is what needs to be straightened out so as not to become a problem in the future. Mu'in (2011: 294) explains "education is the process of character development, character building is the process of shaping the character of the less good to be better". This character building involves the hard work of teachers in classroom learning. Students who have different family backgrounds and parenting styles will shape the character of the student since childhood when he is cared for by his parents. So the teacher optimizes his role as an educator to develop the character of students become more focused and in accordance with the needs of the community.

In the 2013 curriculum, there are topics about weight measurement, and materials that are difficult to be recycled found in everyday life, such as plastic objects. We take the example from school environment where students shop for food using plastic wrappers. If we look in the garbage box, will be found a lot of plastic waste there. Some schools have implemented organic and inorganic waste separation. Students who already understand this separation of garbage will dispose of garbage in accordance with the garbage group. Weighing plastic waste can be an interesting project activity for students. Students are first required to find the history of plastic making and the positive and negative impact of plastic usage in human life. Human needs will be higher plastic along with the human consumptive nature is increasingly rising. Practical plastic as a tool wrapping food and its use after use can be directly disposed of into its own advantages for humans. But the negative impact that is felt now is the inability of plastic waste to be recycled quickly like organic waste. The process of destruction of plastic waste takes up to 20 years, while the need for plastic is getting higher.

In this project the students will weigh how much plastic waste is discharged by their school residents in one day. This activity is done for 4 weeks and will get the average graph of plastic waste weight. Then the students will sort out some of the plastic waste that can be reused for example as a tool of craft or other worthy items and plastic waste that cannot be used anymore. Students are invited to meet plastic craftsman and ask how much plastic waste 
usually required by the craftsmen in making handicraft items such as bags, wallets, goody bags, and others. Then plastic waste that cannot be recycled into handicrafts are weighed and students make predictions about how much plastic weighing might be if multiplied by all schools in the city and in Indonesia. According to the Central Bureau of Statistics in 2016, if in Indonesia has 147 thousand primary schools then the possibility of weight of plastic waste that is not worth recycling is $10 \mathrm{~kg}$. Students are asked to mention the negative impact if plastic waste cannot be recycled. Then students are led to make a short article. The dangers of plastic waste if not recycled is recommended to the government which is hopefully reaffirm the regulations in the use of plastic waste in some goods and food companies that use plastic as a wrapper.

In this project activity the students are trained on how to do the weight measurement and convert it to various weight units that he already knows. In addition they learn environmental pollution caused by garbage. Until here the aspect of ability developed is the cognitive aspect. Then students are asked to think about the negative impact of plastic waste for the life of all human beings in the future. If this case they have found in school then it is possible that the schools that exist throughout Indonesia also have the same case of plastic waste. Students are also invited to write what is the result of their awareness of the negative impact of plastic waste.

\section{CLOSING}

With the research project negative impact of plastic waste is expected to generate awareness in students and society so that the use of plastics should be minimized by bringing goody bag. Reducing the use of plastics saves the earth from non-recyclable plastic waste. Students can also campaign to reduce the use of plastic in the life of the community.

\section{BIBLIOGRAPHY}

Basya, Hassan Syamsi. 2011. Mendidik Anak Zaman Kita. Jakarta: Zaman

Budimansyah, Dasim. 2012. Perancangan Pembelajaran Berbasis Karakter. Bandung: Widya Aksara Press

Mu'in, Abdul. 2011. Pendidikan Karakter. Yogyakarta: Ar-Ruzz Media

Suyadi. 2013. Strategi Pembelajaran Pendidikan Karakter. Bandung: PT Remaja Rosdakarya

Turmudi. 2010. Membangun Karakter Bangsa Bersama Matematika. Potret Profesionalisme Guru dalam membangun Karakter Bangsa. Bandung. UPI Press.558-567 